\title{
AGRICULTURAL ALCHEMY: Stones into Bread
}

\author{
by Ward Chesworth, Felipe Macias-Vazquez, \\ David Acquaye and Edmond Thompson
}

\begin{abstract}
Rising costs and impoverished treasuries are making it ever more difficult for tropical countries to increase food production where fertilizers are required. Moreover, agriculturalists, while adding the major nutrients $N$, $P$ and $K$ in the form of commerically available fertilizer, usually ignore the need to replenish minor nutrients and trace elements in the highly leached soils of the tropics. One solution applicable to regions where weathering rates are high is to use locally available rock material containing the necessary ingredients and to let nature do the rest.
\end{abstract}

\section{The Problem}

In the sixties it seemed appropriate that as part of their training, U.S. astronauts should visit Sudbury in Canada. Here was a region that was, at least superficially, as bleak and sterile as the landscape of the moon, its original vegetation killed off by atmospheric emissions resulting from the smelting of copper and nickel suphides. With the vegetation gone, the bare soil had been washed from the hills into depressions, leaving a landscape dominated by stark rock outcrops.

Today, the large resource companies, sensitive to public opinion and government pressure, employ environmental scientists to correct past abuses and to avoid future ones. In Sudbury, the International Nickel Company has been looking at ways to establish vegetation on mine spoils and to reestablish it on the rock outcrops. One of their major successes has been to grow rye (Fig. 1), following the normal agricultural practice of the developed world by adding commercially available fertilizers. The same practice has been followed by agronomists from many countries in attempting to improve the fertility of highly leached soils in the tropics. There is no doubt that the technique works, but it has two overriding drawbacks. One is economic. Since the energy crises of the seventies, the cost of artificial fertilizer has increased at least three-fold, and most tropical countries are faced by severe restrictions in foreign currency. The second drawback is that commerical fertilizers are invariably incomplete. They look after the major nutrients $\mathrm{N}, \mathrm{P}$ and $\mathrm{K}$, but most of the minor nutrients are left out and plants must fend for themselves.

With this form of agriculture becoming increasingly beyond the means of the developing world, alternatives are needed. We suggest here that the natural geological way in which the planet renews the fertility of soil provides one alternative. To explain this proposition, we begin with a brief consideration of weathering and soil formation.

\section{Weathering and Soil Formation}

The zone of soil formation is a zone of interaction on the earth's land surface between the lithosphere, hydrosphere, atmosphere and biosphere. Weathering is an all-inclusive term for the interactions that take place. Physical weathering plays the important role of breaking up rock fragments and mineral grains, giving chemical weathering an increasingly larger surface area to work on. In soils, several major geochemical environments are recognized though they remain ill-defined (Chesworth et al., 1981). Even so, the fundamen-

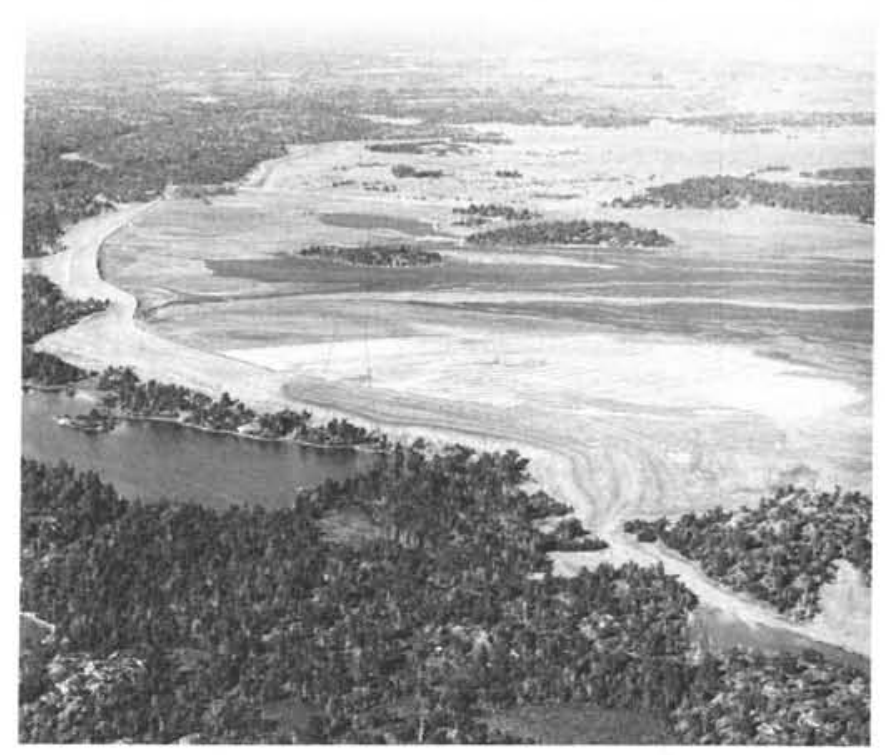

Figure 1: Rye on the rocks. Rye growing on, and stabilizing mine spoil.near Sudbury, Canada.

tal process can be understood as a titration, in that bases contained in the solid phases of the land surface of the earth neutralize acids in a coexisting aqueous phase. The acids come from atmospheric and organic sources, the latter making the chemistry of the zone of soil formation qualitatively different from the weathering zone lower down. Here organic materials are in low concentration, and weathering is dominated by carbonate-bearing waters.

In the humid tropics, the result of this massive titration (or overtitration to be precise) is the acidification of the land and the almost complete replacement of nutrient cations by $\mathrm{H}^{+}$. In the rain forests of Ghana, for example, nutrient-rich granites and greenstones have been converted into soils made up of nutrient-poor combinations of quartz, kaolinite, gibbsite, goethite and hematite soils representative of the refractory, infertile, residua system of weathering, (Chesworth, 1973).

Consider what happens in more detail. A mineral surface is a break in the ideal, electrostatically balanced, mineral structure. It can be thought of as having a number of unsatisfied chemical bonds (e.g. Nichols, 1963). These are ultimately 
satisfied by whatever ions are available in the zone of weathering, and since the commonest available ions are $\mathrm{H}^{+}$ (or $\mathrm{H}_{3} \mathrm{O}^{+}$) and $\mathrm{OH}^{-}$, the surface in general becomes hydroxylated. This process can be looked upon as the first stage of chemical weathering.

The second stage involves the breaking of internal bonds between cations and oxygen, and the ultimate effect of this breakdown is to release hydroxylated ions into the aqueous environment of the zone of weathering. The ions can then be transported in proportion to their solubility in this aqueous environment, which is also commonly oxidizing (i.e. it has a relatively high Eh when not water-saturated) and acid by virtue of dissolved $\mathrm{CO}_{2}$ and organic constituents. In humid climates, $\mathrm{Ca}, \mathrm{Mg}, \mathrm{Na}$ and $\mathrm{K}$ tend to be leached from the soil more rapidly than $\mathrm{Si}, \mathrm{Al}$ or $\mathrm{Fe}$.

The behaviour of these latter three elements relative to one another is often the key to pedogenesis. Under acid conditions and in the presence of organic components for example, $\mathrm{Al}$ and Fe are rendered more soluble and thereby more mobile than Si. Podzolization, dominant in many parts of the northern hemisphere, is the result. In the tropics the organic components are more easily broken down by microbial activity. In their absence $\mathrm{Al}$ and $\mathrm{Fe}$ are less soluble than $\mathrm{Si}$ and so accumulate in the soil. Laterites and bauxites are extreme results of this process.

\section{Soil Fertility}

In general, weathering proceeds through three stages (Fig. 2). Starting from igneous parent materials, for example, the soil progresses from the primary minerals through an intermediate stage where $2: 1$ clay minerals form, to a final stage where $1: 1$ clays and/or hydroxides and oxides predominate (see also Kronberg and Nesbitt, 1981). Clay minerals such as smectite and vermiculite, with a $2: 1$ structure, have a great capacity for storing nutrient ions in loosely held form on their charged surfaces. Thus, soils in the intermediate stage have higher natural fertilities than the initial materials, which have not yet weathered sufficiently to release their stock of nutrients, or than the final materials which are highly leached combinations of $\mathrm{SiO}_{2}, \mathrm{Al}_{2} \mathrm{O}_{3}, \mathrm{Fe}_{2} \mathrm{O}_{3}$ and $\mathrm{H}_{2} \mathrm{O}$.

Given enough time all soils would reach the last stage of low fertility. Fortunately a number of geological processes intervene to renew the fertility of the land and prevent the

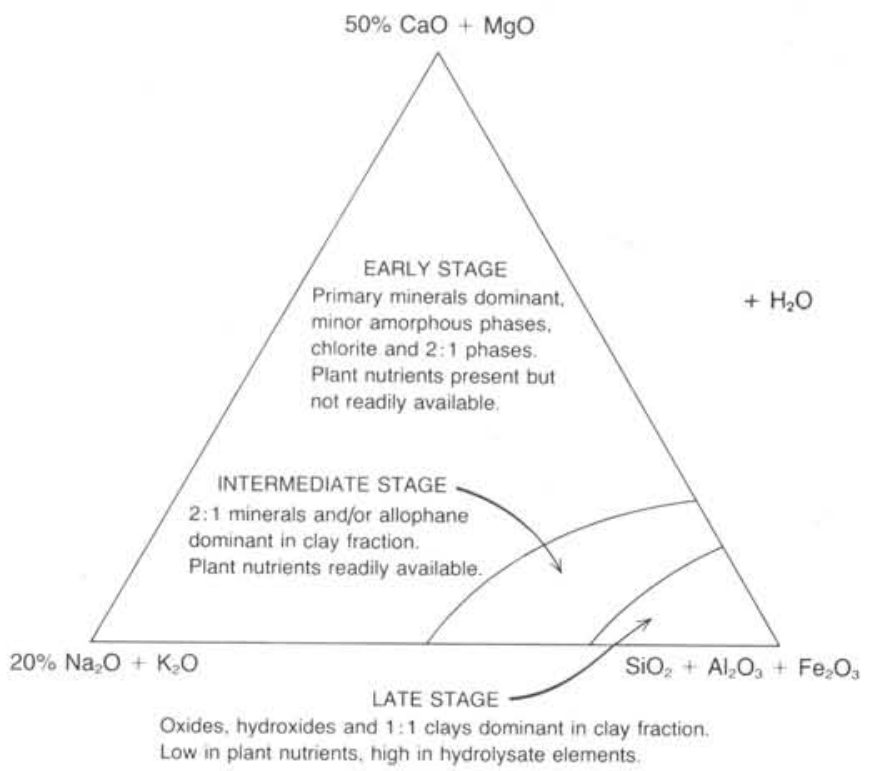

Figure 2: Three gradational stages in the weathering of igneous rocks. The intermediate stage is that of highest inherent fertility. (From Geoscience Canada, vol. 9, p. 57, 1982). surface of the planet from becoming completely barren. They do this by adding fresh rock to the weathering regime, in effect pushing the weathering trend backward (Chesworth, 1975; Fyfe and Kronberg, 1980; Chesworth, 1982).

Many examples of this process of rejuvenation can be cited. Igneous activity in the form of basaltic volcanism accounts for the fertile soils of the Deccan region of India, and of the East African highlands. The Nile redistributes the effects of the latter further afield. Orogeny and attendant volcanism has thrust up new rock in the Cordillera of North and South America, in the Atlas mountains of North Africa, and in a wide belt of Eurasia stretching from the Alps, through the Himalayas, to Indonesia. Where topographic limitations have

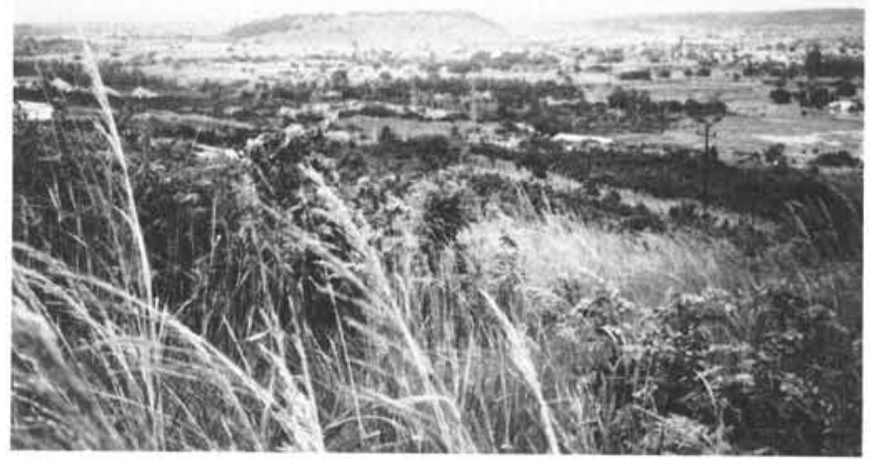

Figure 3: Accra Plain, Ghana. In the FAO soil classification, the soil is an acrisol over most of the landscape. It is highly leached and its mineralogy is dominated by quartz and kaolinite.

been overcome by terracing, the soils of these regions have proved very productive. In the higher latitudes of the northern hemisphere and in smaller areas of the southern hemisphere, old weathered surfaces have been scraped clean and new rocks have been exposed by ice sheets. Wind and water have reworked and redistributed this new material to produce fertile loess deposits in Europe, the Americas and Asia. Finally, fresh sedimentary rocks have been exposed by marine regressions to form the basis of fertile soils, for example around the gulf of Mexico and in southern Australia.

It is noteworthy that the continents with the most extensive areas of highly productive and inherently fertile soils are the ones like North America and Eurasia, that have had their land surfaces renewed in one or another of the above ways in the geologically recent past. Where such processes have not been lately active on a large scale (e.g. in most of Africa and Australia, and much of South America east of the Andes) the landscape has achieved the third stage of weathering and is inherently of low fertility (Fig. 3). All this suggests that a possible strategy for maintaining the fertility of the land artificially would be to use common and readily available rocks as fertilizers. Logically, this is bound to work if the weathering rate is fast enough, and in the humid tropics this condition appears to hold.

The logic of this strategy has been obvious for at least 130 years. For example Magnus (1850) used powdered feldspar to provide K for a barley crop. Missoux (1853) found crushed granite to be a useful source of plant nutrients. Aitken (1887), Balentine (1889), Hartwell and Pember (1908), and Cushman (1907) all record successful early experiments in using feldspar as a source of plant K. Coleman (1977) provides a thorough bibliography of these and later studies. 
It is noteworthy that Keller (1948), with his long and impressive record in the study of weathering, was one of the earliest of modern geologists interested in the possibility of using rocks as fertilizers.

\section{Common Rocks as Soil Additives}

In order for a common rock to sustain a crop, it would have to be capable of reacting with soil water to give a concentration of nutrient elements in solution sufficiently high to take care of the needs of growing plants. To take potassium as an example, the solution would need to maintain about $4 \mathrm{ppm} \mathrm{K}$ (Russell, 1974). Following the lead of Kronberg (1977), we have performed a large number of experiments at the University of Guelph in which crushed acid to basic igneous rock was saturated with water and left to react for up to ten days at $25^{\circ} \mathrm{C}$ and one atmosphere pressure. Within the first hour the level of $\mathrm{K}$ in the water rose to about $15 \mathrm{ppm}$ in some cases, probably indicating a reaction with very fine particles. After this initial surge the level dropped to a steady 6 to 10 $\mathrm{ppm}$, clearly enough for plant nutrition. A similar story holds for most of the major plant nutrients with the exception of $\mathrm{N}$ and in most cases of P. However, there is no doubt that many common igneous rocks could be used as the basis of an artificial fertilizer, with $\mathrm{P}$ added if necessary and $\mathrm{N}$ provided by an intercrop of legumes.

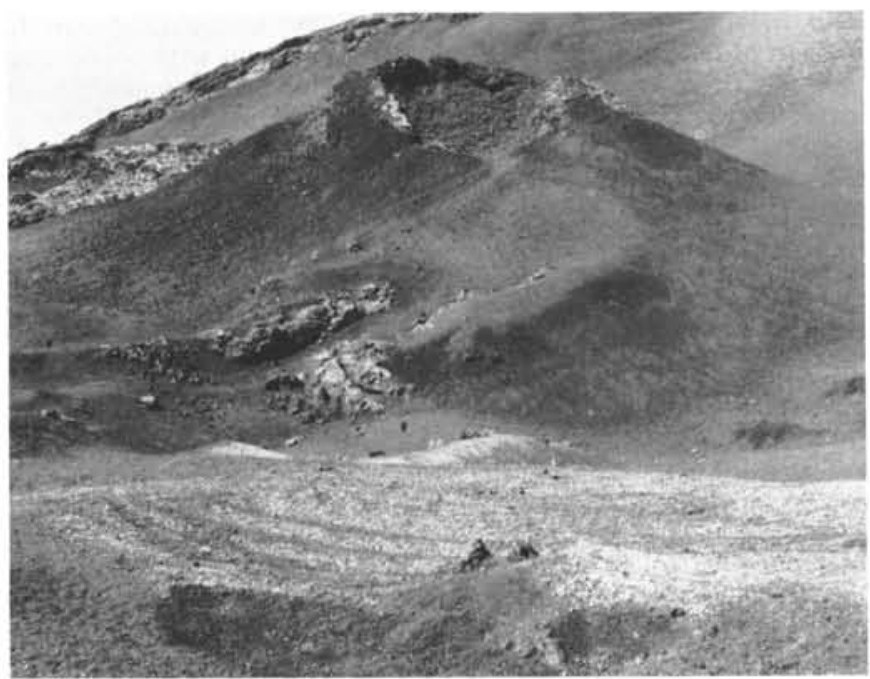

Figure 4: Small (15 meter high) cindercone, Lanzarote, Canary Islands. Basaltic scoria of this kind is the source of the fertility of the island.

As with most good, simple ideas in agriculture, somewhere in the world a farmer can be found to have anticipated the scientist. Such is the case in the Canary Islands. Here, for roughly the last two hundred years, an intensive agriculture has developed in which volcanic rock (Fig. 4) has been used as a soil amendment. On Tenerife for example, terraces have been constructed and scoriaceous phonolite has been laid on them as a bed for plants (Figs. 5 \& 6). The rock does not need crushing, being already loose and friable, and in the semi-tropical climate, weathering is fast enough to maintain a crop. Nitrogen is added as conventional fertilizer but the rock provides everything else.

In the same group of islands, Lanzarote provides an example of a different use of volcanic rock as a soil amendment. The problem here is one of insufficient moisture, for the soils are formed on weathering basalts and are of high fertility. The climate is arid and normally much like that of the Sahara. It is however, modified by the close proximity of the sea, and during the night a heavy dew falls. Unfortunately when the sun rises all moisture is lost by rapid evaporation. Again the local farmers have evolved an ingenious solution. Dark

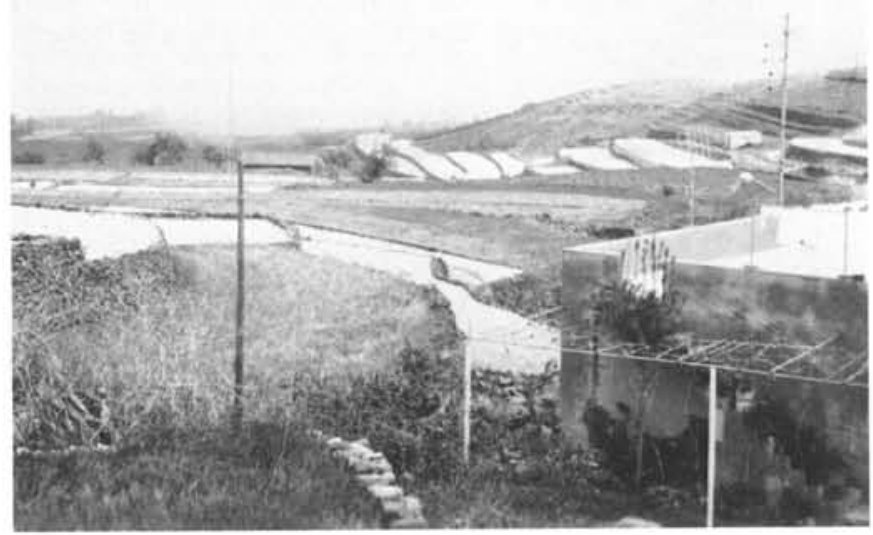

Figure 5: Agricultural terraces on Tenerife, overlaid with light coloured scoriaceous phonolite.

basaltic scoria is used to cover the soil and to act as a reservoir to conserve the dew. The result is that many crops flourish, including grapes, figs, corn, onions and beans (Figs. $7,8)$.

Thus a "folk technology" exists that demonstrates the usefulness of rock not only as a soil fertilizer but also as a means of extracting moisture from humid atmospheres. It is a technology that can be exported to many parts of the world and especially to many tropical regions. Here the vast savannahs and rain forests with acid, infertile soils constitute "the largest block of potentially arable but virtually unused land in the world" (Sanchez, 1981). Here also sources of appropriate rocks exist, as for example, volcanic scoria in places like the Cameroons and East Africa, greenstones and amphibolites in Brazil and Ghana. In fact, it is in Ghana that we are currently investigating the possibilities of conducting trials at Kade and Tafo, agricultural stations in the rain forest. That basic rock here is particularly valuable in raising the fertility of soil, is indicated by how much better the rain forest flourishes on the Archaean greenstones than on the granites.

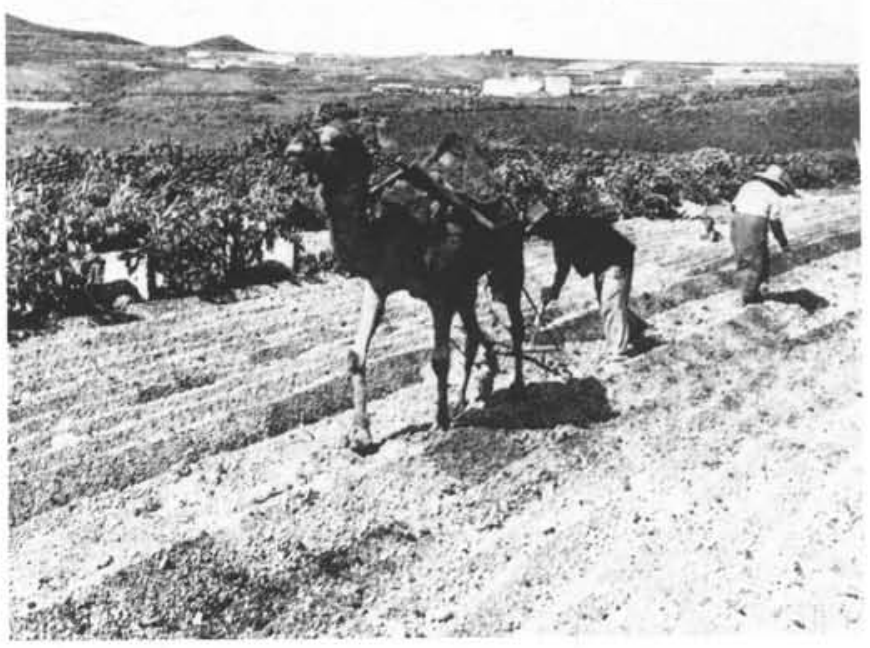

Figure 6: Grapes growing on phonolitic soil, Tenerife (Photo by Ediciones Gasteiz). 
Furthermore, the government of Kuwait is interested in testing the Lanzarote method of extracting water from humid air and has made a formal request of the Spanish government for help (Fernandez Caldas, pers. comm.). Many other coastal regions with arid climates might also benefit from the technique.

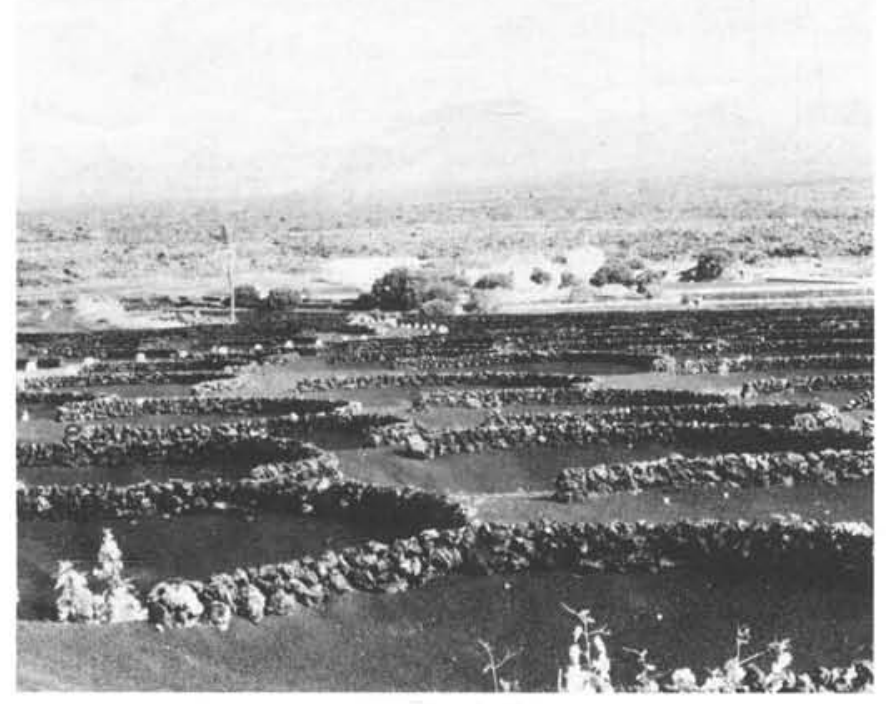

Figure 7: Grapes arowing in soil covered with scoriaceous basalt on Lanzarote. The basalt walls are windbreaks.

\section{Conclusions}

"Expanding the world's agricultural frontier is ... part of the overall strategy toward world food self-sufficiency" (Sanchez, 1981). It is a humane and desirable objective, and one in which geologists no less than soil scientists have an essential role to play. We have shown that there is sufficient evidence to justify field trials in the humid tropics using crushed rock as a soil additive. Agronomists have resisted the idea mainly because the success of modern chemical and biological technology in the agriculture of the temperate zone, when judged in terms of yield and profit, has been so spectacular. For the most part, therefore, they have had little compunction in proposing the same techniques in the



Figure 8: Beans and corn growing on the scoria of Lanzarote. developing world. Only lately have horror stories been publicized concerning the adverse environmental effects of this attitude (see Pearse, 1981).

Interestingly, foresters have been less conservative in their outlook than agriculturalists. Crushed basalt has been used successfully by several workers in Northern Europe as a source of forest nutrition (e.g. Albert, 1938, 1940; Gerth, 1939). And not all agronomists have been blind to the possibilities. De Villiers, for example, used crushed basalt to improve over-cropped soils in the humid districts of Mauritius (1949).

Given that such a strategy is worth trying, there still remain many questions to be answered. We need research on the efficacy of different rocks and minerals as additives, on the optimum grain size and on where the economic cut-of $f$ lies in the energy-intensive process of grinding, on what soils are most conducive to such treatment and on what species of plants can most efficiently extract their nutrition from these geological sources (Coleman, 1977). And, if we are to avoid yet another disastrous intervention into the agriculture of the tropics, we need to study carefully the long term effects of this technique on the physical and chemical nature of the soil, as well as on the hydrological regime and the ecosystem at large.

Our most optimistic expectations are no less than the realization of an old dream: "What will fertilizing with stone dust accomplish? It will turn stones into bread... make barren regions fruitful (and) feed the hungry" (Hensel, 1894).

\section{Acknowledgements}

We are grateful to Dr. E. Fernandez Caldas and his faculty at the University of La Laguna in Tenerife for their help in the Canary Islands, and especially to Dr. Marisa Tejedor Salguero, who provided the original of Figure 5. David Coyle gave invaluable bibliographic assistance. We also thank the International Nickel Company of Canada for the photograph used as Figure 1.

\section{References}

Aitken, A.P., 1887. Ground felspar as a potash manure. Transactions Highland Society, Scotland, v. 19, p. $253-$ 261 .

Albert, R., 1938. On the use of fine debris from stone quarries for the improvement of poor forest soils. Forstarchiv, v. 14, p. 229-240.

Albert, R., 1940. Investigations on the effect of complete ploughing and basalt fertilizing at various depths. Forstarchiv, v. 16, p. 231-232.

Balentine, W., 1889. Experiments with feldspar as a source of potash. Maine Agricultural Experimental Station Annual Report (1889), p. 143-150.

Chesworth, W., 1973. The residua system of chemical weathering: a model for the chemical breakdown of silicate rocks at the surface of the earth. Journal of Soil Science, v. 24, p. 69-81.

Chesworth, W., 1975. Geochemical behaviour of elements during weathering. In: Miller, M.H. (ed.), Metals in the Biosphere, University of Guelph, p. 99.

Chesworth, W., 1982. Late Cenozoic geology and the second oldest profession. Geoscience Canada, v. 9, p. 54-61.

Chesworth, W., Dejou, J., and Larroque, P., 1981. The weathering of basalt and relative mobilities of the major elements at Belbex, France. Geochimica et Cosmochimica Acta, v. 45, p. 1235-1243.

Coleman, E., 1977. The use of ground rock powders in agriculture. Harborside, Maine, p. 23. 
Cushman, A.S. 1907. The use of feldspathic rocks as fertilizers. U.S. Department of Agriculture Bureau of Plant Industry Bulletin, 104, p. 33.

de Villiers, O. d'H., 1949. Fur ther studies on the rejuvenation of exhausted soils in humid districts by incorporating basalt dust. Revue Agricole et Sucriere de l'lle Maurice, v. 28, p. 124-134.

Fyfe, W.S. and Kronberg, B.I., 1980. Nutrient conservation: the key to agricultural strategy. Mazingira, v. 4, p. 6469.

Gaucher, G., 1977. Vers une classification pedologique naturelle basée sur la géochimie de la pedogenese. Catena, v. 4, p. 1-27.

Gerth, G., 1939. The possibilities of rock meal as a soil improver, and their significance for the rock quarrying industries. Forstarchiv, v. 15, p. 435-436.

Hartwell, B.L. and Pember, F.R., 1908. Experiments with feldspathic rock as a source of potassium. Roy. Inst. Agric. Ex. Station Bull. 129, p. 27.

Hensel, J., 1894. Bread from Stones. A.J. Tafel, Philadelphia, p. 116.

Keller, W.D., 1948. Native rocks and minerals as fertilizers. Science Monthly, v. 66, p. 122-130.

Kronberg, B.I., 1977. The geochemistry of some Brazilian soils and geochemical considerations for agriculture on highly leached soils. Unpublished Ph.D. thesis, University of Western Ontario, p. 137.

Kronberg, B.I. and Nesbitt, H.W., 1981. Quantification of weathering, soil geochemistry and soil fertility. Journal of Soil Science, v. 32, p. 453-459.

Magnus, G., 1850. Uber die Ernährung der Pflanzen. Journal Praktische Chemie, v. 50, p. 65-75.

Missoux, P., 1853. Sur l'emploi de la poudre des rockes granitiques comme excitant de la vegetation. Comptes Rendus Hebdomadaires des Seances de l'Academie des Sciences, v. 36, p. 1136.

Nicholls, G.D., 1963. Environmental studies in sedimentary geochemistry. Science Progress, v. 51, p. 12-31.

Pearse, A., 1981. Seeds of Plenty, Seeds of Want. Clarendon Press, Oxford, 262p.

Russell, E.W., 1974. Soil Conditions and Plant Growth. Longman, London, 10th edition, 867p.

Sanchez, P.A., 1981. Soil management in the Oxisol savannahs and Ultisol jungles of tropical South America. In: Greenland, D.J. (ed.), Characterization of Soils, Clarendon Press, Oxford, Chapter 12, p. 446.

\section{ABOUT THE AUTHORS:}

Dr. Ward Chesworth holds a Ph.D. in geochemistry from McMaster University, and has worked in Canada, U.S.A., U.K., France, Spain and Ghana. He now teaches geology and geochemistry in the Department of Land Resource Science of the University of Guelph, Guelph, Ontario, Canada N1G 2W1. Dr. Chesworth's main research interests are phase equilibria and mineral-water interactions at low PT.
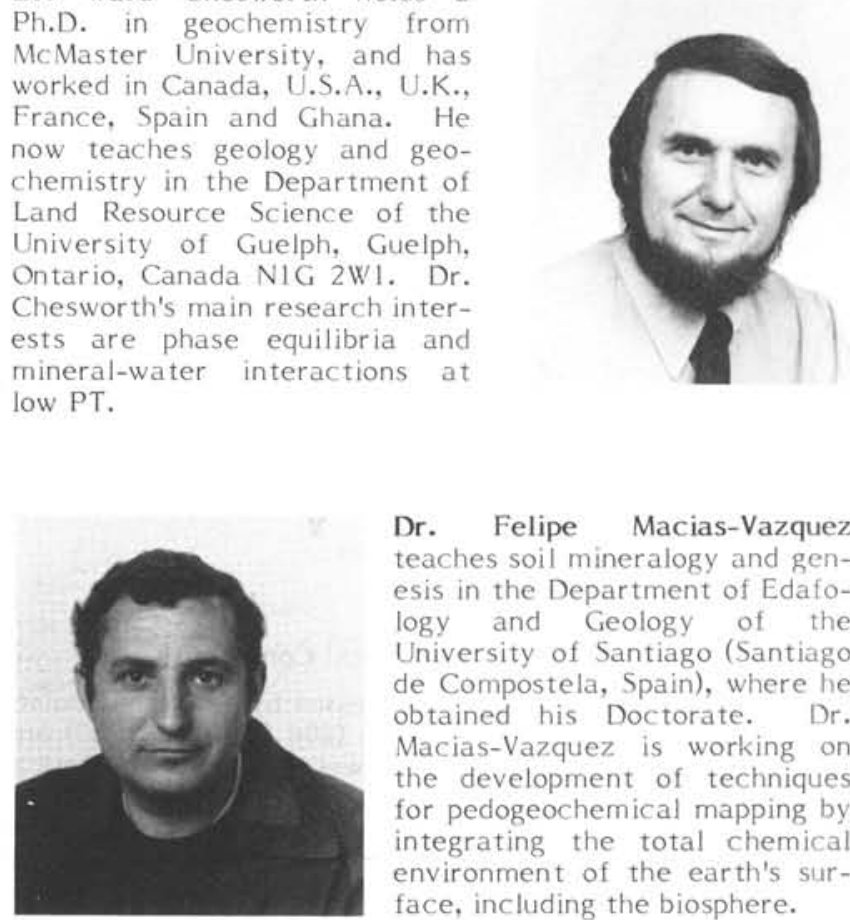

Dr. Felipe Macias-Vazquez teaches soil mineralogy and genesis in the Department of Edafology and Geology of the University of Santiago (Santiago de Compostela, Spain), where he obtained his Doctorate. Dr. Macias-Vazquez is working on the development of techniques for pedogeochemical mapping by integrating the total chemical environment of the earth's surface, including the biosphere.

Dr. David Acquaye is involved in research on the fertility of tropical soils, with a particular interest in the dynamics of potassium release. Dr. Acquaye holds a Ph.D. in soil science from the University of Aberdeen and now teaches soil genesis and fertility at the University of Ghana, Legon, Ghana.

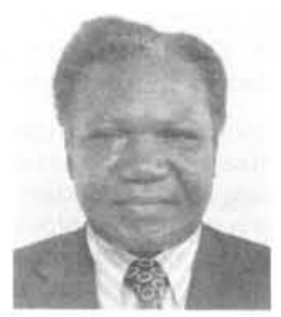

Now teaching at the University of Sierra Leone, Dr. Edmond Thompson has been involved in the study of soil genesis for some time. Dr. Thompson obtained his Ph.D. in Soil Science from the University of Iowa. He was Dean of Agriculture of the University of Ghana from 1977 to 1980. (Photo not available)

"Chemical weathering is the dominant process by which continental surfaces are modified. The chemical weathering cycle requires millions of years, and the chemical weathering time-clock may be reset by tectonic processes which introduce fresh rock debris (glaciation, volcanism, alluviation).... The classic example is in the Indonesian archipelago, where Java's volcanic soils produce abundant crops of grain, while nearby Borneo lying in the same climatic zone has virtually no intensely cultivated land (because its) land surface is geologically old and lacks abundant fresh rock debris" (B.I. Kronberg and H.W. Nesbitt, 1981).

"Most of the constraints imposed by Amazon soils on agricultural development are chemical rather than physical in nature. ... Continuous production can be achieved in the Amazon with adequate fertilization." (P.A. Sanchez et al., Science, May 21, 1982). 